\title{
Association between Anti-prejudice Norm and Attitudes towards Minority Groups
}

\author{
Tátila Rayane de Sampaio Brito, 2 \\ Cicero Roberto Pereira ${ }^{1}$ \\ ${ }^{1}$ Psychology at the Federal University of Paraíba, UFPB, João Pessoa, Paraíba, Brasil \\ ${ }^{2}$ Lisboa, Portugal
}

\begin{abstract}
In this study we investigated the relationship between the anti-prejudice norm and the expression of attitudes towards minority groups. Participated 100 people who evaluated a list with 16 target groups of prejudice, answering two questions: indicate the groups that feel less prejudice; and which ones do you prefer. The results showed that there are different levels of prejudice depending on the target-group, with the women, blacks and people with disabilities being the most protected by the norm. A hierarchical analysis of clusters evidenced an organization of the groups, classified as naturalised, blamed, sexual and political minorities. The anti-prejudice norm and the attitudes presented a strong and positive relation $(r=0.65, p<0.001)$. A multilevel logistic regression analysis showed that this relation was moderated by the type of group. These results contribute to the studies on the expression of prejudice, besides demonstrating the role of norms in the understanding of the phenomenon.

Keywords: hierarchy; prejudice; social minority.
\end{abstract}

\section{Relação entre Norma Antipreconceito e Atitudes frente a Grupos Minoritários}

\section{Resumo}

Neste estudo investigamos a relação entre a norma antipreconceito e a expressão de atitudes frente a grupos minoritários. Participaram 100 pessoas que avaliaram uma lista com 16 grupos-alvo de preconceito, respondendo a duas perguntas: indique os grupos que sente menos preconceito; e quais os que mais prefere. Os resultados indicaram que há níveis diferentes de preconceito consoante o tipo de grupo-alvo, sendo os grupos de mulheres, negros e pessoas com deficiência os mais protegidos pela norma. Uma análise hierárquica de clusters evidenciou uma organização dos grupos, classificados como naturalizados, culpabilizados, minorias sexuais e políticas. A norma antipreconceito e as atitudes apresentaram uma relação forte e positiva $(r=0,65 ; p<0,001)$. Uma análise de regressão logística multinível mostrou que essa relação foi moderada pelo tipo de grupo. Tais resultados contribuem aos estudos sobre a expressão do preconceito, além de demonstrarem o papel das normas na compreensão do fenômeno.

Palavras-chave: hierarquia, preconceito, minorias sociais

\section{Relación entre Norma Anti-prejuicio y Actitudes frente a Grupos Minoritarios}

\section{Resumen}

En este estudio investigamos la relación entre la norma anti-prejuicio y la expresión de actitudes frente a grupos minoritarios. Participaron 100 personas que evaluaron una lista con 16 grupos que sufren prejuicio, respondiendo a dos preguntas: indique los grupos que siente menos prejuicio; y los que más prefiere. Los resultados demuestran que hay niveles diferentes de expresión del prejuicio según el tipo de grupo, siendo los grupos de mujeres, negros y personas con discapacidad los más protegidos por la norma. Un análisis jerárquico de clusters evidenció una organización de los grupos, clasificados como naturalizados, culpabilizados, minorías sexuales y políticas. La norma anti-prejuicio y las actitudes presentaron una relación fuerte y positiva $(r=0,65, p<0,001)$. Un análisis de regresión logístico multinivel mostró que esta relación fue moderada por el tipo de grupo. Tales resultados contribuyen a los estudios sobre la expresión del prejuicio, además de demostrar el papel de las normas en la comprensión del fenómeno.

Palabras clave: jerarquía; prejuicio; minorías sociales.

There is ample evidence in the literature that the public expression of prejudice towards minority groups has decreased over the last forty years. In other words, people say that they are not prejudiced, even though their behaviour shows the occurrence of objective discrimination (Lima, 2016; Lins, Lima-Nunes \& Camino, 2014; Pinto \& Ferreira, 2014). The social psychology of prejudice and discrimination has shown that this dissociation is motivated by pressure from the antiprejudice norm (e.g. Crandall, Eshleman \& O’Brien,
2002; Gaertner \& Dovidio, 1986). This norm is based on values of equality as a fundamental principle that should regulate social relations (Schwartz, 2015), and it is present in the legal and normative systems of many western countries.

In fact, the antiprejudice norm has been institutionalised in several official documents. For example, article 5 of the Federal Constitution of Brazil (1988) states that "all are equal before the law, without distinction of any kind", and the Brazilian Penal Code 
guarantees that "crimes resulting from discrimination or prejudice by reason of race, colour, ethnic group, religion or national origin shall be punished" (Law No. 7.716/89). Although the normative system prohibits discrimination against various social groups, empirical evidence nonetheless shows that some groups are afforded greater social protection than others (Batista et al, 2014; Pereira \& Souza, 2016; Schwarcz \& Neto, 2017).

This suggests that, although the institutionalisation of the antiprejudice norm has resulted in fewer instances of the public expression of discrimination, this has not led to its effective internalisation in people's value systems as an organising principle of their lives. Thus, the control of the public expression of prejudice, but not its private rejection, indicates that people act only out of mere conformity with normative prescriptions, since they are motivated to avoid social sanctions (Modesto et al, 2017; Pereira \& Souza, 2016) and to protect their public image (Pereira, Álvaro \& Vala, 2018). Thus, it is possible to detect a dissociation between the public acceptance of the antiprejudice norm and the maintenance of negative attitudes towards minority groups.

\section{The Social Psychology of Antiprejudice}

Sherif and Sherif (1953) developed a theory, known as the Group Norm Theory, according to which norms are the main factors explaining attitudes and social behaviour. In short, they suggested that people feel pressure to conform to the norms of the groups of which they form part and that individual attitudes are, in fact, simply the reproduction of the attitudes of the group to which they belong. This perspective seems of interest in trying to understand why people tend to state publicly that they are not prejudiced, but, on the other hand, consider that there is prejudice in the society in which they live (Camino et al, 2001). This suggests the possibility that people are under the influence of two normative systems, corresponding to two types of norms: descriptive versus injunctive (Deutsch \& Gerard, 1955). Descriptive norms refer to what is more frequent or common in a certain group, while injunctive (or prescriptive) norms relate to what is socially approved or admired by the group.

It is likely that attitudes towards minority social groups involve some compromise solution between the two normative systems. Although the public expression of prejudice is condemned for various groups (i.e. antiprejudice is prescriptive), there is evidence that prejudice still persists at the descriptive level (Gaertner \& Dovidio, 1986; Lima \& Vala, 2004).

Some studies have used the normative perspective (França \& Monteiro, 2013; Pettigrew, 1991; Staunton et al, 2014) to explain the expression of prejudice (Crandall et al, 2002; Crandall, Ferguson \& Bahns, 2013; McDonald \& Crandall, 2015; Pauker, Apfelbaum \& Spitzer, 2015; Schultz et al, 2018). According to this line of thought, one way of reducing prejudice is by giving greater prominence to egalitarian social norms.

For example, Lima et al., (2006) undertook three studies in which they highlighted the role of normative contexts in the automatic prejudice displayed towards black people. In the first study, they assessed the effects of two types of normative contexts (egalitarian and meritocratic) and one neutral context on automatic prejudice. In the second study, they investigated the social representations of equality. And, finally, in the third study, they constructed two types of egalitarian normative contexts (formal versus supportive egalitarianism), which, together with the context of competitive meritocracy, enabled them to analyse the impact of these norms on automatic prejudice. In short, the results of their research demonstrated that the meritocratic context increases people's expression of prejudice, while the egalitarian context does not reduce prejudice, but only eliminates the automatic activation of the negative attitude towards black people.

Walker, Sinclair and MacArthur (2015) investigated the role of social norms in the expression of attitudes towards homosexual rights. Specifically, they assessed the participants' political beliefs, their attitudes towards homosexual rights and their motivation to control their prejudiced reactions. After submitting them to two experimental conditions (the norm of anti-homosexual rights and the norm of pro-homosexual rights), they discovered that, in the condition of "pro-homosexual rights", there was a greater change of attitude in the participants in conforming to the norm than in the condition of "anti-homosexual rights". Furthermore, they showed that not all individuals respond equally to the pressures of the social norm.

Crandall et al (2002) tested the hypothesis that people follow social norms when they express prejudice, having two sources of motivation: an external one, which consists in adapting to the rules of the group; and another internal one, referring to the person's identification with the reference group and his or her internalisation of the norms. Specifically, they investigated whether the public expression of 
negative attitudes in relation to 105 social groups was related with the social approval (or not) of such expression. The results showed that there were groups about which it was acceptable to express negative attitudes, with rapists, child abusers and thieves at the top of the list. On the other hand, it was less acceptable to express negative attitudes about racial groups or disabled people. Furthermore, they found a strong correlation between the expression of negative attitudes towards the different groups and the extent to which participants considered that group to be protected by the antiprejudice norm.

Despite providing important contributions for understanding the role of norms in explaining prejudice, none of the above-mentioned studies presented results about the way in which people organise social groups. So, what are the organising principles of the differences between these groups? In this study, we shall attempt to fill in this gap and thus contribute to the literature about the relationship between social norms and the expression of prejudice towards minority groups.

Prejudice is defined as a negative assessment of a group or of a person because he or she belongs to a particular group (Allport, 1954; Devine, 1989). This negative attitude may be guided by some principles, such as beliefs shared between people about the nature of each social group (Medin \& Ortony, 1989; Moscovici, 1961).

Various research studies have demonstrated the role of common-sense theories about the nature of social groups as organising principles that serve to maintain prejudice (Lacerda, Pereira \& Camino, 2002; Pereira et al, 2011). This line of thought is followed, for example, by the studies about psychological essentialism (Bastian \& Haslam, 2006), which propose that the categorisation of objects results in a process that defines the nature of social elements (Medin \& Ortony, 1989). According to Rothbart and Taylor (1992), we attribute different essences to groups, based on how we perceive them, for example as natural or social.

This interpretation has been used to analyse the structure of essentialist beliefs in understanding intergroup attitudes (Haslam, 2017; Ho, Roberts \& Gelman, 2015). Furthermore, the perspective of social representations (Moscovici, 1961; Moscovici \& Hewstone, 1983) also understands the categorisation of groups as the result of an organisation based on common-sense theories, or socially shared beliefs about the nature of social groups. Through processes of anchorage and objectivation, people construct and disseminate beliefs about the nature of groups, facilitating the process of categorisation (anchorage) and stereotyping (objectivation). In short, the perspective of social representations, mainly representations about the nature of groups, understands that, through the beliefs that people have about the nature of social groups, there is a maintenance of the discriminatory practices that such groups suffer, considering also that these beliefs, in general, contribute to the maintenance of the status quo.

Pereira et al (2011) investigated the way in which prejudice against homosexuals was maintained through common-sense theories in Catholic and Protestant seminarists. The results showed that the participants presented two types of prejudice: the first was referred to by the authors as blatant prejudice, while the second was referred to as subtle prejudice. They observed that Protestants were more blatant, whereas Catholics were more subtle. Furthermore, the authors identified the fact that beliefs about the nature of homosexuality explained the differentiation between those who were subtle and those who were blatant in their prejudice. Those who were subtle in their prejudice were anchored in biological beliefs, founded upon natural and innate aspects; while those who were blatantly prejudiced based their attitudes on ethical and moral beliefs.

Pereira, Torres and Pereira (2004) undertook a study about the relationship between social representations and prejudice towards prostitutes in a sample of Catholic and Protestant theology students. They found that prejudice towards prostitutes was organised in three dimensions: rejection of relations of proximity, negative emotions and positive emotions. Based on the normative perspective, they demonstrated that the group of prostitutes was not so well protected by the norm, since a widespread prejudice against them was identified. However, the authors also demonstrated that this widespread prejudice displayed certain variations. The Protestant students presented higher levels of prejudice in comparison with the Catholics, and these variations were related with the representations that both types of students had about the nature of prostitution.

Following this line of thought, in this research, we investigate whether there are differences in the expression of prejudice towards different target groups. Furthermore, we assess whether there exists a hierarchy of prejudice and analyse its organisation in the light of the normative perspective and the abovedescribed organising principles. Specifically, we seek 
to answer the following questions: (1) Which minority social groups are most protected by the antiprejudice norm? (2) Towards which groups do people express the most positive attitudes? (3) What is the relationship between the antiprejudice norm and individuals' attitude towards groups? and (4) Is there some organising principle governing attitudes towards social groups? The answers to these questions call for an analysis of the main aspects underlying the social psychology of the antiprejudice norm.

\section{Method}

\section{Participants}

Our sample consisted of 100 participants, with ages varying between 18 and 47 and an average age of 25 (SD $=6.27)$. Most of the participants were women $(70 \%)$.

\section{Instruments}

We developed a list of social groups that are the target of prejudice, based on the one compiled by Crandall et al (2003). The list was composed of sixteen groups, including examples where Brazilian norms tend to condemn prejudice more strongly (e.g. women and black people) and groups where the norms are not so protective (e.g. feminists and prostitutes). All the groups comprising the list are shown in Figure 1.

Normativity was assessed with the following question: "From the list of groups below, select the three towards which you feel least prejudice". The groups that were selected were attributed with the number 1 (a group protected by the norm), while those that were not selected were attributed with 0 (a group not protected by the norm). The positive attitude towards the groups was measured through the question: "In the following list, please indicate the eight groups that you like most". The selected groups were attributed with the code 1 (positive attitude), while those that were not selected were attributed with the code 0 (negative attitude). The aim was to assess whether the participants distinguished the target groups towards which they expressed positive attitudes from those towards which they nurtured negative attitudes, in keeping with their personal attitudes towards each of them.

\section{Procedure}

Our research project was submitted to an ethical committee, and, after receiving a favourable opinion (CAAE 89390918.0.0000.5188), we began to collect data. The selection of participants was based on convenience, being made through a call placed on the social media. After reading the terms of informed consent and agreeing to take part in the research, the participants were sent a questionnaire by e-mail and, after answering the questions, they returned them by e-mail. The data were computed on the statistical software SPSS, version 21.

\section{Data Analysis}

The data were analysed using the statistical software SPSS, in its version 21: descriptive statistical analyses were carried out (mean, standard deviation and frequency), together with hierarchical cluster analysis, correlation analysis and variance analysis (ANOVA) with paired contrasts and multilevel logistic regression.

\section{Results}

The results are presented according to the answers to the research questions proposed in this investigation. First of all, descriptive statistical analyses were carried out, in order to answer the first question in the questionnaire, which corresponded to the first problem that was proposed: "Which minority social groups are most protected by the antiprejudice norm?". Figure 1 presents the indicative proportions of each group for which the participants stated that they did not feel prejudice, i.e. the groups that are protected by the antiprejudice norm. The results indicated that the groups suffering least from prejudice were mainly women, black people and unemployed people, whereas those that were least protected were people with HIV/Aids, prostitutes and transsexual and transgender people. Below (Figure 1), it is possible to identify a hierarchy with all 16 groups, ranging from those that were most protected by the norm to those that were least protected.

Next, the analyses were directed towards the answers to the second question, about people's positive attitudes towards groups. A change was noted in the arrangement of the groups, mainly in the ordering of those groups towards which people expressed the most positive attitudes, which were black people, followed by women and disabled people. The following figure (Figure 2) shows the distribution, taking into account all the target groups.

In order to answer the third question, about the relationship between the antiprejudice norms and people's attitudes towards groups, i.e., what extent the indicative proportions of normativity (question 1) and positive attitudes (question 2) are related, a Pearson 
correlation analysis was undertaken. The proportions observed for each group in the two questions were used. The analysis demonstrated a strong and positive correlation between the two variables $(r=0.65, p<$ 0.001). This means that the more anti-normative it was to express prejudice towards a target group, the more the participants declared that they had a positive attitude towards this group.
Next, in order to assess the organising principles of people's attitudes towards social groups, a non-parametric hierarchical cluster analysis (HCA) was carried out, corresponding to the fourth research question. The results show four general categories into which the groups were organised (Figure 3).

According to the result found in the dendrogram, it can be seen that the groups were organised into four

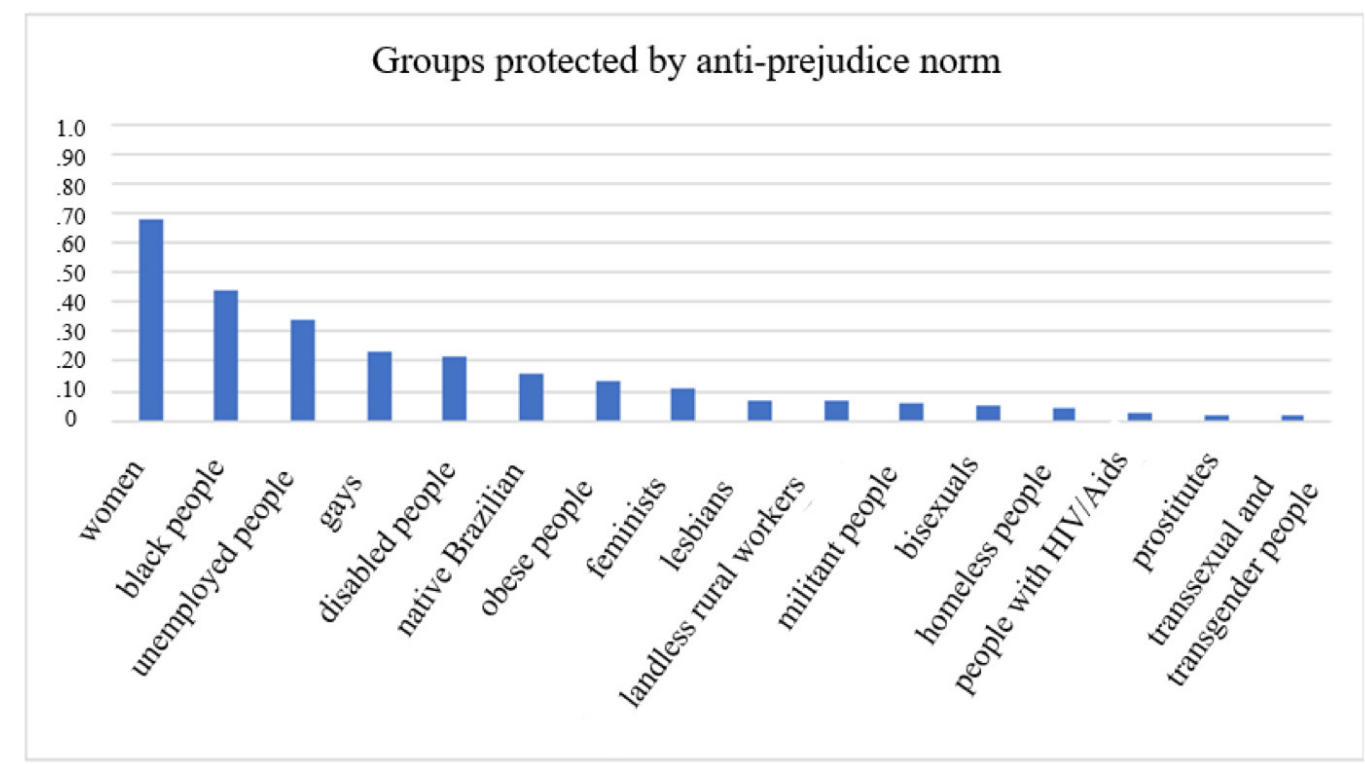

Figure 1. Groups protected by anti-prejudice norm.

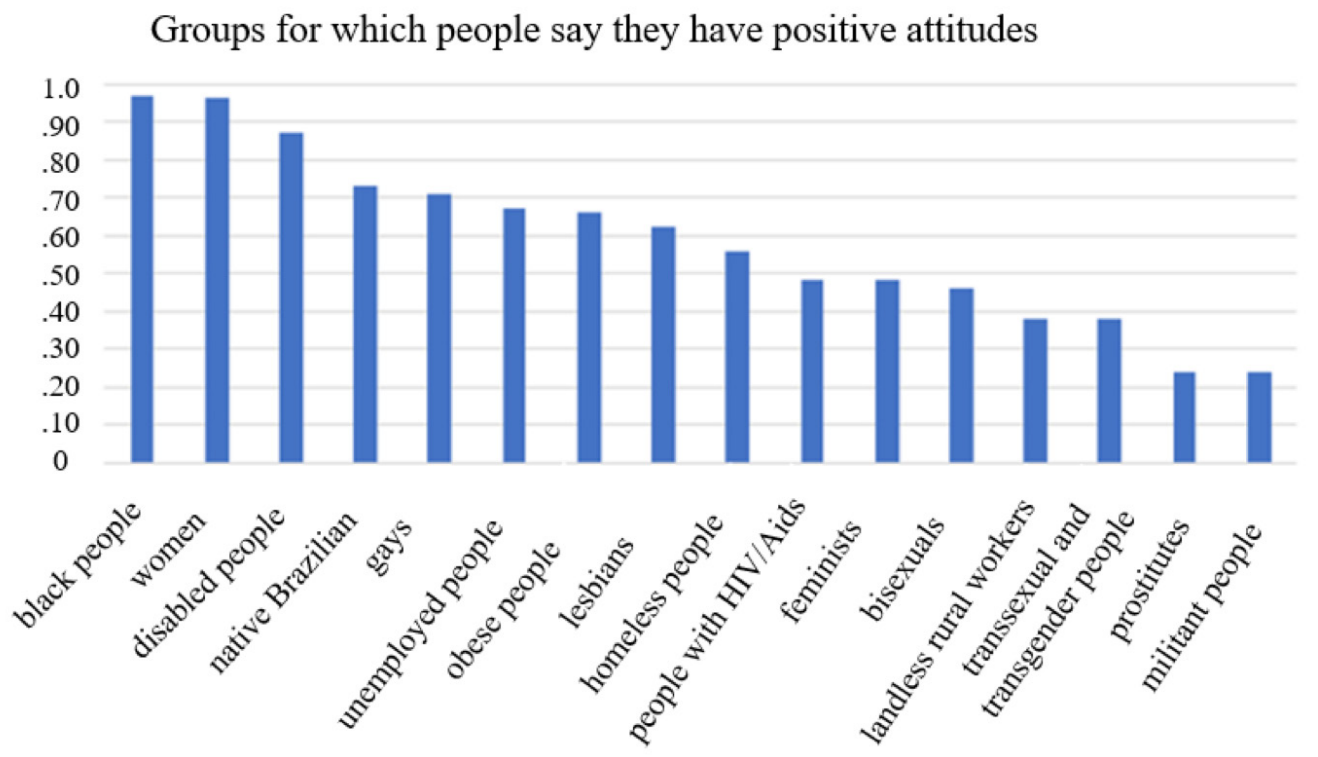

Figure 2. Groups for which people say they have positive attitudes. 


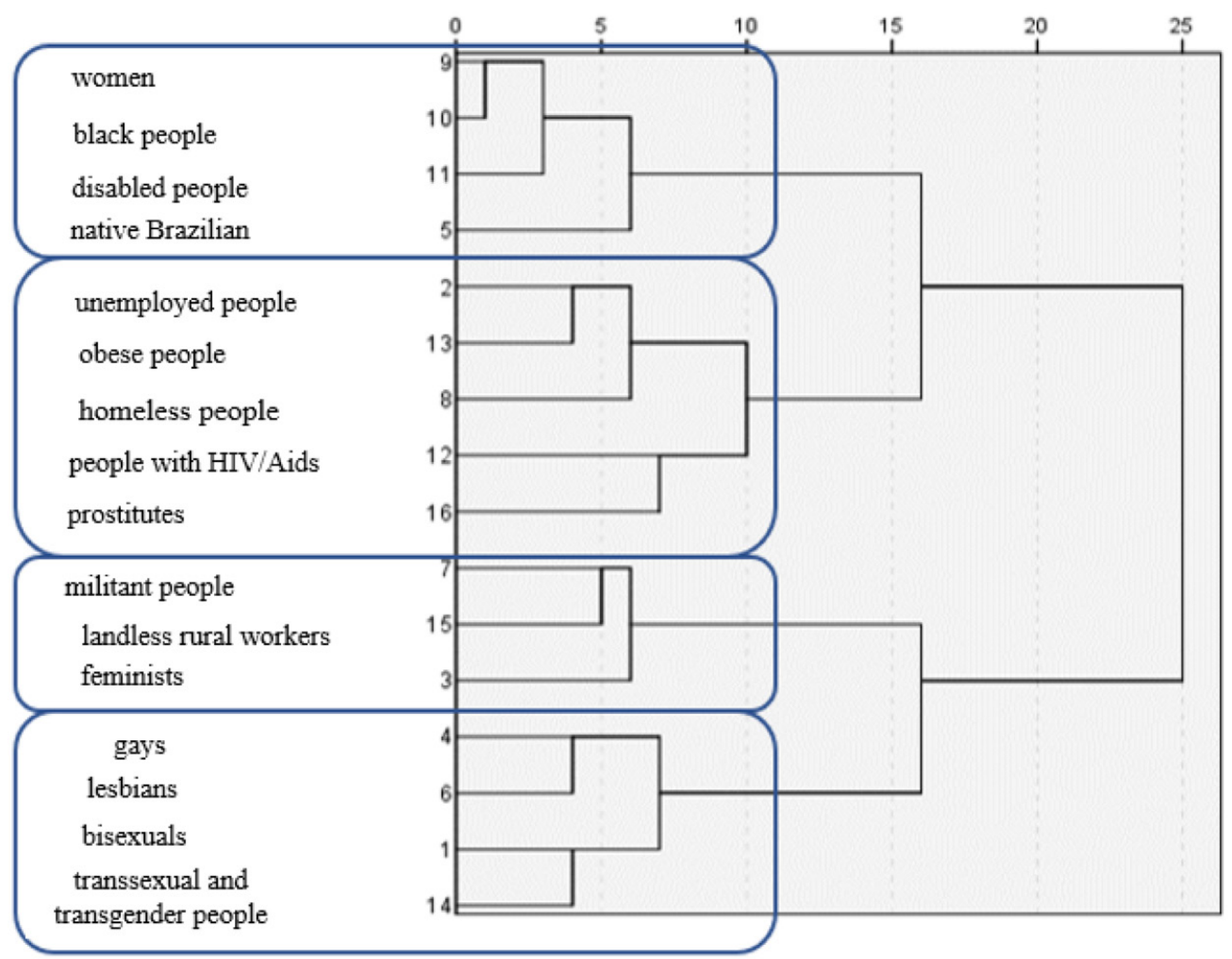

Figure 3. Dendrogram with minority group classes.

categories. The first is formed by the groups women, black people, disabled people and native Brazilian. This category may be called naturalised groups. The second category is composed of the groups unemployed people, obese people, homeless people, people with HIV / Aids and prostitutes. This category may be called blamed groups. The third category formed from the groups militant people, landless rural workers and feminists was given the name of political minorities. Finally, the fourth category was classified as sexual minorities since it was composed of the groups gays, lesbians, bisexuals and transsexual and transgender people.

Based on such evidence, an Analysis of Variance (ANOVA) was carried out, comparing the means of the preferences between the categories with the aim of discovering how individuals organised the social groups according to how much they preferred certain groups (or not). The results of the ANOVA reveal significant differences, $F(1,98)=5024.467, p<0.001$, indicating a hierarchy of people's preferences towards different types of target group. Once the presence of a hierarchy of preferences had been identified, we sought to check how the comparisons were made specifically. Multiple comparisons were thus made, which indicated significant differences between the naturalised groups and all the rest $(p<0.001)$, above all in comparison with the political minorities group, with this latter group being assessed as being the least preferred by the participants. There was no difference between the sexual minority groups and the blamed groups. These results will be discussed in the light of the normative perspective and the organising principles of attitudes.

As can be seen, there is a hierarchy in the expression of prejudice, which begins with those groups that are most protected socially by the antiprejudice norm (naturalised groups) moving down to those for whom the norm is not so active (political minorities). It can further be seen that there was almost no difference in the expression of prejudice towards the blamed groups and the sexual minorities. On a scale that ranged from 0 to 1 , both of them scored roughly a half (around 0.5), which indicates that people demonstrated extreme positioning only when they assessed how much they preferred naturalised groups and political minorities.

After identifying the relationship between norms and attitudes and the categorisation of the 16 groups 
into general classes, we posed the question whether the type of group moderates the relationship between the normativity of people's prejudices and the choice of their preferred group. To answer this question, it should be remembered that the dependent variable (the choice of group) is dichotomous and the participants answered $(0=$ did not choose and $1=$ chose $)$ for each of the 16 groups. This means that we have a hierarchical data structure, in other words, 16 choices for each individual. For this reason, the answer to the research problem that we posed must be obtained through a multilevel logistic regression analysis. However, given the high correlation between the antiprejudice norm and the expression of attitudes towards the target groups, we undertook a preliminary analysis in order to inspect the matrix of correlations between the variables, which showed that there were no problems of collinearity among the variables under analysis (VIF $=1.44$; Tolerance $=0.69$; Conditional Index varying between 1 and 5.03), making it possible to undertake the regression with terms of interaction for testing the moderation hypotheses.

We undertook such an analysis, considering the positive attitudes towards the groups as a dependent variable, the antiprejudice norm as an independent variable and the type of group (naturalised, blamed, sexual minorities and political minorities) as a moderating variable. The results indicated that both the role of the norm $[F(1,98)=54.653, p<0.001]$ and the type of group $[F(3,96)=7.657, p<0.001]$, as well as the interaction norm*type of group $[F(3,96)=4,540$, $p<0,005]$ were significant in predicting the positive attitudes of the participants. This interaction signifies that the relationship between normativity and attitudes is moderated by the type of group, i.e., the norm impacts differently on the choices of the participants, depending on the group.

To better interpret the interaction, we made a breakdown of the effect of the antiprejudice norm on individuals' attitudes in each type of group (Figure 4). As can be seen, when the norm is around zero (i.e. when the group is not protected by this norm) the expression of positive attitudes towards the groups varies. The political minorities group is the least preferred among the people taking part, whereas the group of naturalised people is viewed more positively. On the other hand, when the antiprejudice norm is high (i.e. when the group is protected by this norm), all the groups are assessed as positive. In other words, what explains the choice of the group as the one preferred by the participants is the perception that expressing prejudice against that group is antinormative. Indeed, the differences between the groups disappear when the expression of negative attitudes is antinormative. When this perception was absent, the participants selected different types of group, with the political minorities being considered less favourable and the naturalised groups being considered more favourable. This means that the representation about the nature of the group plays an important role, besides normativity.

In short, it was seen that norms have an effect on the expression of positive attitudes, but this effect is moderated by the type of target group involved. The effect was greatest in the political minorities group $(B=$ $18.12, p<0.001)$, followed by the sexual minorities group $(B=5.84, p<0.001)$, the naturalised group $(B=4.41$, $p<0.001)$ and the blamed group $(B=3.66, p<0.001)$.

Effect of anti-prejudice norm on expression of positive attitudes, moderated by target group type

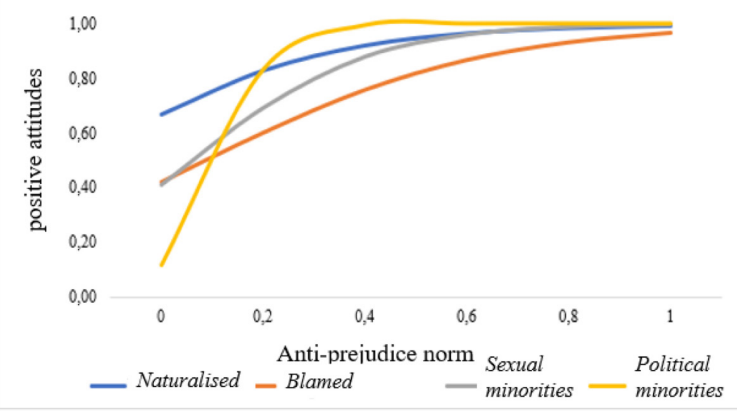

Figure 4. Effect of anti-prejudice norm on expression of positive attitudes, moderated by target group type.

\section{Discussion}

The analysis of the results was conducted from a psychosocial perspective that takes into account the role played by the norms and social representations that people have about groups in the suppression and expression of prejudice and the positive attitudes that they feel towards social minorities. Although the norms and representations were not assessed in an explicit way, the results showed that people presented an underlying logic that enabled them to categorise the groups into general classes. Such categorisation implicitly reflects the beliefs that people have about the nature of groups. We will discuss the findings of this study in 
detail, following a line of thought that is coherent with the proposed research questions.

The first research question sought to identify which groups were most protected by the antiprejudice norm. The results suggested that the expression of prejudice was regulated by a normative framework, since it was coherent with the pattern already identified in previous studies (Crandall et al, 2002). Women and black people were to be found at the top of the list, since these were considered as the groups least targeted by prejudice. In other words, the groups for which there is greatest social disapproval of the expression of discrimination. At the opposite end of the list are the transsexuals, prostitutes and people with HIV/Aids. These groups are less protected by the antiprejudice norm, i.e. participants consider it acceptable to express prejudice towards them.

To some extent, the people belonging to these groups are perceived as being responsible for their acts, and this result mainly indicates that the Brazilian normative context does not exert any strong pressure to condemn discrimination towards groups who have sexual behaviours that are perceived as different from the traditional heteronormative pattern (Alencar, Neves \& Parente, 2016; Freires, 2015). The most disturbing feature is that, as they are not protected by the antiprejudice norm, these are the groups that are the greatest victims of aggression and violence in Brazil (Bonassi et al, 2015), as pointed out in the study by Silva et al (2016). In a sample of transvestites and transsexuals, the authors analysed the types of violence to which they were subjected and revealed that $91 \%$ had already been victims of verbal violence, $58 \%$ psychological violence and $33 \%$ physical violence.

In short, as far as the first research question is concerned, it can be concluded that, through the presence of the word "prejudice" in the questionnaire itself, some mechanism was activated in people that motivated them to answer in accordance with what would be most socially acceptable or appropriate (Schultz et al, 2018), thereby suffering some impact. In this case, from the Brazilian prescriptive antiprejudice norms (Deutsch \& Gerard, 1955).

The second research question related to mapping the target groups of people's positive attitudes, when they had to express their personal attitudes, without having any specific normative framework as their point of reference. From the differences between the results shown in Figures 1 and 2, it was evident that, besides the normative pressures, there are organising principles of attitudes that exert an influence on the expression of such attitudes. In order to analyse these principles, and in answering the fourth research question, we observed how the groups were organised, which enabled us to identify the logic whereby the attitudes express a wellstructured categorisation of the target groups.

This framework makes it possible to understand how people express attitudes towards social groups based on specific shared characteristics. For example, when people expressed positive attitudes towards women, they also did so when the targets were black people, disabled people and Brazilian Indians, since they anchored these groups in one single social representation about their nature (Rothbart \& Taylor, 1992), objectifying them as a general class. In the same way, in preferring feminists, they also preferred landless rural workers and all militant groups in general. These generalisations show that the way in which we perceive social groups is associated with the way in which we will relate to them.

As was demonstrated by Pereira et al (2011), those social groups that are perceived as natural were treated by people as more acceptable when compared to others. Moscovici (1961) already defended that, when we classify them, we define groups and people according to how much they diverge (or not) from the norm, considering the role of what is socially desirable as our guide in the process of categorisation.

When people are confronted with a social group for the first time, they anchor the new information in a set of beliefs that is already established in their cognitive system, and they see the new group as similar to old ones. This process explains how different groups are categorised, and, by classifying them, people reveal their theories about the social reality (Moscovici \& Hewstone, 1983). In order to analyse these aspects more deeply, we can discuss the results corresponding to the third research question that we posed: is there a relationship between norms and attitudes?

We partly refute what Crandall and collaborators (2002) had supposed when they stated that attitudes would be a direct reflection of norms, treating the two variables as if they were overlapping ones. Furthermore, the results shown here fill in the gap in the studies about the relationship between norms and attitudes, by demonstrating that it is the type of group which moderates that relationship. In other words, when there are no antiprejudice norms, the expression of attitudes is guided by the representation that people have about the nature of each group. Thereafter, and considering the 
categorisations, they publicly express prejudice, especially towards groups that are not perceived as natural.

In terms of social impacts, these findings show the need to construct a discourse that leads to a greater internalisation of the antiprejudice norm towards all minority social groups, since this can serve as an antidote for preventing the expression of negative attitudes that lead to the formation of prejudice against these groups. If all groups were equally protected by the antiprejudice norm, then the aggressions displayed towards specific categories, such as black people, women and homosexuals, might probably begin to show a downward trend over time, thus contributing towards transforming the scenario of discrimination in the Brazilian context.

\section{Conclusions}

The findings of this present study open up new research avenues about the relationship between norms and prejudice, which may be followed in other studies. Although it is highly relevant, this research is not without its limitations. The first of these is the fact that we have used a small sample that was chosen out of convenience. In this case, it is suggested that future studies should be undertaken with larger samples and with the greatest possible coverage of the various sectors of society. Furthermore, other variables might play an important role in determining the relationship between norms and the expression of attitudes, such as, for example, the type of group that the participant belongs to. Since this study may be considered exploratory in nature, it was not possible to take into account the wide diversity of variables that may be relevant for studying the problem of the expression of prejudice, so that we focused exclusively on those that responded to the research problems that we raised. This being the case, attention is drawn to this investigation's potential contribution to future studies that seek to enlarge upon the findings demonstrated here, as well as the need to use more explanatory variables, giving special attention to the role that the participant's group of belonging may play in the relationship between norms and attitudes towards minority target groups. For example, in qualitative studies with members of each of the categories (naturalised groups, blamed groups, sexual and political minorities), it would be important to study how each person expressed prejudice towards their own group in comparison with other groups.

Another important limitation to be taken into consideration has to do with the questionnaire that we used for the collection of data. This questionnaire was composed exclusively of explicit questions, making it possible to study only the public expression of prejudice. In subsequent studies, it is suggested that implicit measures may be used to access attitudes and test whether there are differences when the hierarchy of private attitudes is being assessed. However, despite the limitations mentioned, this study can provide an important contribution to the literature about the relationship between norms and prejudice, where prominence is given to the fact that this relationship depends on people's perceptions about the nature of social groups.

\section{References}

Allport, G. W. (1954). The nature of prejudice. Oxford, England: Addison-Wesley

Bastian, B., \& Haslam, N. (2006). Psychological essentialism and stereotype endorsement. Journal of Experimental Social Psychology, 42(2), 228-235. doi. org/10.1016/j.jesp.2005.03.003.

Batista, J. R. M., Leite, E. L., Torres, A. R. R., \& Camino, L. (2014). Negros e nordestinos: similaridades nos estereótipos raciais e regionais. Revista Psicologia Politica, 14(30), 325-345.

Bonassi, B. C., Amaral, M. S., Toneli, M. J. F., \& Queiroz, M. A. (2015). Vulnerabilidades mapeadas, Violências localizadas: Experiências de pessoas travestis e transexuais no Brasil. Cadernos de Psicologia, 17, 8398. doi.org/10.5565/rev/qpsicologia.1283.

Brasil. Constituição (1988). Constituição da República Federativa do Brasil. Brasília, DF: Senado Federal: Centro Gráfico.

Camino, L., Silva, P. D., Machado, A., \& Pereira, C. (2001). A face oculta do racismo no Brasil: Uma análise psicossociológica. Revista de psicologia política, 1(1), 13-36.

Crandall, C. S., Eshleman, A., \& O’brien, L. (2002). Social norms and the expression and suppression of prejudice: the struggle for internalization. Journal of Personality and Social Psychology, 82(3), 359- 378. doi.org/10.1037/0022-3514.82.3.359.

Crandall, C. S., Ferguson, M. A., \& Bahns, A. J. (2013). When we see prejudice: The normative window and social change. In C. Stangor \& C. S. Crandall (Eds.), Frontiers of social psychology. Stereotyping 
and prejudice (pp. 53-69). New York, NY, US: Psychology Press.

Deutsch, M., \& Gerard, H. B. (1955). A study of normative and informational social influences upon individual judgment. The journal of abnormal and social psychology, 51(3), 629-636. doi.org/10.1037/ h0046408.

Devine, P. G. (1989). Stereotypes and prejudice: Their automatic and controlled components. Journal of personality and social psychology, 56(1), 5-18. doi:10.1037/0022-3514.56.1.5.

França, D. X., \& Monteiro, M. B. (2013). Social norms and the expression of prejudice: The development of aversive racism in childhood. European Journal of Social Psychology, 43(4), 263-271. doi.org/10.1002/ ejsp.1965.

Gaertner, S. L., \& Dovidio, J. F. (1986). The aversive form of racism. San Diego, CA, US: Academic Press.

Haslam, N. (2017). The origins of lay theories: The case of essentialist beliefs. In The science of lay theories (pp. 3-16). Springer, Cham.

Ho, A. K., Roberts, S. O., \& Gelman, S. A. (2015). Essentialism and racial bias jointly contribute to the categorization of multiracial individuals. Psychological Science, 26(10), 1639-1645. doi.org/10.1177/0956797615596436.

Lacerda, M., Pereira, C., \& Camino, L. (2002). Um estudo sobre as formas de preconceito contra homossexuais na perspectiva das representações sociais. Psicologia: reflexão e crítica, 15 (1), 165-178. doi.org/10.1590/S0102-79722002000100018

Lima, T. J. S. D. (2016). O papel de representações sobre raça e classe social no preconceito e discriminação. Tese (Doutorado em Psicologia Social) - Universidade Federal da Paraíba.

Lima, M. E. O., Pinheiro, C. M., Ávila, J. P., Lima, C., \& Vala, J. (2006). Normas sociais e preconceito: o impacto da igualdade e da competição no preconceito automático contra os negros. Psicologia: Reflexão e Critica, 19(2), 309-319.

Lima, M. E. O., \& Vala, J. (2004). As novas formas de expressão do preconceito e do racismo. Estudos de Psicologia, 9(3), 401- 411.

Lins, S. L. B., Lima-Nunes, A. V., \& Camino, L. (2014). O papel dos valores sociais e variáveis psicossociais no preconceito racial brasileiro. Psicologia \& Sociedade, 26(1), 95-105.

McDonald, R. I., \& Crandall, C. S. (2015). Social norms and social influence. Current Opinion in Behavioral Sciences, 3, 147-151. doi.org/10.1016/j. cobeha.2015.04.006.

Medin, D. \& Ortony, A. (1989). Psychological essentialism. In. S. Vosniadou \& A. Ortony (Eds.), Similarity and analogical reasoning (pp. 183-196). New York: Cambridge Academic Press.

Modesto, J. G., Minelli, A. C., Fernandes, M. P., Rodrigues, M., Bufolo, R., Bitencourt, R., \& Pilati, R. (2017). Racism and Affirmative Action: Evidence for the Justified Discrimination Model. Psicologia: Teoria e Pesquisa, 33, 1-8. doi. org/10.1590/0102.3772e3353.

Moscovici, S. (1961). La psychanalyse, son image et son public. Paris: Presses universitaires de France.

Moscovici, S., \& Hewstone, M. (1983). Social representations and social explanations: From the "naive" to the "amateur" scientist. In. M. Hewstone (Ed.), Attribution theory: Social and functional extensions (pp. 98-125). Oxford: Blackwell.

Pauker, K., Apfelbaum, E. P., \& Spitzer, B. (2015). When societal norms and social identity collide: The race talk dilemma for racial minority children. Social psychological and personality science, 6(8), 887-895. doi.org/10.1177/1948550615598379.

Pereira, C. R., Álvaro, J. L., \& Vala, J. (2018). The EgoDefensive Role of Legitimacy: How Threat-Based Justifications Protect the Self-Esteem of Discriminators. Personality and Social Psychology Bulletin, 44(10), 1-14. doi.org/10.1177/0146167218771007.

Pereira, C., Torres, A. R. R., \& Pereira, A. (2004). Preconceito contra prostitutas e representações sociais da prostituição em estudantes de teologia católicos e evangélicos. Estereótipos, preconceito e discriminação: Perspectivas teóricas e metodológicas, 209-234.

Pereira, C. R., \& Souza, L. (2016). Fatores Legitimadores da Discriminação: Uma Revisão Teórica. Psicologia: teoria e pesquisa, 32(2), 1-10. doi. org/10.1590/0102-3772e322222.

Pereira, C., Torres, A. R. R., Pereira, A., \& Falcão, L. C. (2011). Preconceito contra homossexuais e representações sociais da homossexualidade em Psico-USF, Bragança Paulista, v. 25, n. 3, p. 507-518, jul./set. 2020 
seminaristas católicos e evangélicos. Psicologia: Teoria e Pesquisa, 27(1), 73-82.

Pettigrew, T. F. (1991). Normative Theory in Intergroup Relations: Explaining Both Harmony and Conflict. Psychology and Developing Societies, 3(1), 3-16. doi. org/10.1177/097133369100300102.

Pinto, M. C. C., \& Ferreira, R. F. (2014). Relações raciais no Brasil e a construção da identidade da pessoa negra. Revista Pesquisas e Práticas Psicossociais, 9(2), 256-266.

Rothbart, M., \& Taylor, M. (1992). Category labels and social reality: Do we view social categories as natural kinds? In G. R. Semin \& K. Fiedler (Eds.), Language, interaction and social cognition (pp. 11-36). Thousand Oaks, CA, US: Sage Publications, Inc.

Schultz, P. W., Nolan, J. M., Cialdini, R. B., Goldstein, N. J., \& Griskevicius, V. (2018). The constructive, destructive, and reconstructive power of social norms: Reprise. Perspectives on psychological science, 13(2), 249254. doi.org/10.1177/1745691617693325.

Schwarcz, L., \& Neto, H. M. (2017). Quando o passado atropela o presente: notas de um Brasil que insiste no racismo. Cadernos de Campo, 25(25), 31-35. doi. org/10.11606/issn.2316-9133.v25i25p31-35.
Schwartz, S. H. (2015). Basic individual values: Sources and consequences. Handbook of value, 63-84.

Sherif, M., \& Sherif, C. W. (1953). Groups in harmony and tension; an integration of studies of intergroup relations. Oxford, England: Harper \& Brothers.

Silva, G. W. D. S., Souza, E. F. L., Sena, R. C. F. D., Moura, I. B. D. L., Sobreira, M. V. S., \& Miranda, F. A. N. D. (2016). Cases of violence involving transvestites and transsexuals in a northeastern Brazilian city. Revista gaucha de enfermagem, 37(2), 1-7. doi. org/10.1590/1983-1447.2016.02.56407.

Staunton, M., Louis, W. R., Smith, J. R., Terry, D. J., \& McDonald, R. I. (2014). How negative descriptive norms for healthy eating undermine the effects of positive injunctive norms. Journal of Applied Social Psychology, 44(4), 319-330. doi.org/10.1111/ jasp.12223.

Walker, B. H., Sinclair, H. C., \& MacArthur, J. (2015). Social norms versus social motives: the effects of social influence and motivation to control prejudiced reactions on the expression of prejudice. Social Influence, 10(1), 55-67. doi.org/10.1080/1553 4510.2014 .904247$.

Recebido em: 05/10/18

Reformulado em: 30/04/2019

Aprovado em: 28/08/2019 
Acknowledgments:

This work was partially supported by a grant from Coordenação de Aperfeiçoamento de Pessoal de Nível Superior with a doctoral scholarship awarded to Tátila Rayane de Sampaio Brito and by a grant from the Fundação para a Ciência e a Tecnologia, awarded to Cicero Roberto Pereira (PTDC/PSI-GER/30928/2017).

About the authors:

Tátila Rayane de Sampaio Brito - Psychologist at the Federal University of Piauí - UFPI (2015) and Master in Social Psychology at the Federal University of Paraiba - UFPB (2017). She is currently a PhD student in Social Psychology at UFPB. Her research interests include psychological assessment focusing on psychological testing; quantitative procedures for data collection and analysis; studies on factors that legitimise prejudice, intergroup and interpersonal relationships and their role in the processes of discrimination and conflict resolutions.

ORCID: https://orcid.org/0000-0002-1282-5558

E-mail: tatila.rayane@hotmail.com

Cicero Roberto Pereira is Full Professor of Social Psychology at the Federal University of Paraíba and an Associated Research at the Institute of Social Sciences of the University of Lisbon. His studies analyse how and in which conditions social actors in contemporary democratic societies legitimise their attitudes and actions supporting prejudiced and discriminatory policies against minority groups.

ORCID: https://orcid.org/0000-0003-3406-3985

E-mail: crp@labesp.org

Contact:

Departamento de Psicologia - CCHLA, Campus I, Castelo Branco I

João Pessoa-PB, Brasil

CEP: 58051-900 